From the Media Periodicals

by Richard Ellis

CLASSROOM COMPUTER LEARNING, 5:2, Sept. 1984 Kohl, Herbert. "Who should be evaluating software?" Kohl, Herbert. "Who should be evaluating software"
Sharp, Pamela. "USing Logo to shape artistic ideas""
Green, John O. "Straight talk about local networks"

CLASSROOM COMPUTER LEARNING, 5:3, Oct. 1984 Slesnick, Twila. "Should software pirates walk the plank?" cate'"
Copeland, Willis D. "Creating a historian's microworld" CLASSROOM COMPUTER LEARNING, 5:4, Nov/Dec. 1984 Ohanian, Susan. "How today's reading software can zap kids' dergen, Steve and Lynne Schalman. "Who's pushing the but-
Berit."

COMPUTERS IN EDUCATION, Sept. 1984

Allan, Roger. "Major CL systems"'
Lenk, Frank. "Logo: opening doors"

Lenk, Frank. "Logo: opening doors"
Allan, Roger. "School computers in Canada"
Koprin, Lia. "Computer assisted testing operations"

COMPUTERS IN EDUCATION, Oct. 1984

Zapletal, Edward. "Networking"'
Markwick, William. "A look at the Icon"

Markwick, William. "A look at the Icon"
Marshall, George R. "Word processing: teaching approaches"

EDUCATIONAL COMMUNICATION AND

TECHNOLOGY, 32:2, Summer 1984

Ganske, Ludwig and Pauline Hamamoto. "Response to crisis: A developer's look at the importance of needs assessment to
teacher educators in the design of computer literacy training programs"
Heinich, Robert. "The proper study of instructional technology"

EDUCATIONAL COMMUNICATION AND J

Jonassen, David H. "The mediation of experience and educa-

EDUCATIONAL TECHNOLOGY, 24:8, August 1984 Marcus, Stephen. "GOSUB: POET: RETURN - Computers and the poetic muse"
Stiehl, Ruth E. and Les D. Streit. "Factors assuring success Stiehl, Ruth E. and Les D. Streit. "
of an instructional systems model"

of an instructional systems model"
Schwade, Stephen. "Why keyboard entry convenience should not be your only concern when choosing courseware: the advantages of the constructed response"
Goodman, R. Irwin. "Focus group interviews in media product
testing"

EDUCATIONAL TECHNOLOGY, 24:9, September 1984 Ehrmann, Stephen C. "'Technology could change the goals of
a college education..."
Carrier, Carol A. and Judith L. Lambrecht. "Preparing teachers for using computers in instruction"
Thomas, Dwain. "A high school evaluates software (with an evaluation form)" Selfe, Cynthia L. "Software for hardnoses: CAI for college composition teachers" Cruz, Jaume. "A critical review of programmed instruction"
Waldrop, Phillip b. "Behavior reinforcement strategies for computer-assisted instruction: programming for success. Idya, Sheila and John Mckeeby. "Computer turtle graphics:

EDUCATIONAL TECHNOLOGY, 24:10, October 1984 Salomon, Gavriel. "Computers in education: Setting a research agenda"
Masat, Francis E. "A regional approach to computer education of teachers: A case study"

Wallace, Joy and Raymond M. Rose. "A hard look at software: What to examine and evaluate (with and evaluation form)"
Sandoval, Hugo F. "Teacher training in computer skills: A call for a redefinitio

Young, Jerry L. "The case for using authoring systems to develop courseware"
Della-Piana Gabriel and Connie Kubo Della_Piana. "Computer software information for educators: A new approach to portrayal of student tryout data"
Reider, William L. "Video-cassette technology in education: A quiet revolution in progress"
Rees, Elwyn, et al. "Complex analysis of classroom interacRees, Elwyn, et al. "Complex analysis of classroom
tions using RACER computer-based technology"

JOURNAL OF COMPUTER-BASED INSTRUCTION, 11:3, Jummer 1984

Bark, Alfred. "Producing computer based learning material at the Educational Technology Center"
Mudrick, David and David Stone. "An adaptive authoring sys-

tem for computer-based instruction"
Avner, Allen, et all "CBI authoring tools: Effects on productivity and quality"
Fairweather, P.G. and A.F. O'Neal. "The impact of advanced Hannafin, Michael J. "Options for authoring instructional

MEDIA \& METHODS, 21:1, September 1984

Radencich, Marquerite C. and Jeanne S. Schumm. "To byte
or not to byte: Traditional and high-tech approaches to writing term papers"

MEDIA \& METHODS, 21:2, October 1984

Dyrenfurth, Michael J. and F. Milton Miller. "An ongoing Pinola, Mary. "How effectively do you use media?" Sokoloff, Michele. "Surprising connections: Linking technology to curriculum"
Walcott, J. Andrew. "Orchestrating the media center"

Continued on page 16.

VOLUME 14, NUMBER 2, 1985

Mediography

MEDIA ON COMMUNICATION

by Nancy Lane

The topic for this issue is communication. I have listed a number programs which portray a variety of aspects and viewpoints.

COMMUNICATING NON-DEFENSIVELY MOtion Pictire MGHT 198225 min., sd., col.

Defensive communication - when and why; and a plan of counteraction are explored in this presentation.

COMMUNICATION: THE NAME OF THE GAME Motio Picture RTBL//TF $198-28$ min., sd., col. change ideas and information.

COMMUNICATION: NON-VERBAL AGENDA Motio Picture MGHT 197430 min., sd., col.
Examples of non-verbal communication are demonstrated
to show the effects on interpersonal relationships. With Dr. to show the effects on interpersonal relationships. With D

COMMUNICATION - A SERIES Motion Picture COR 1977 approx. 14 min. ea., sd., col.
These three films deal with the message, the receiver, and the sender.

COMMUNICATION BY VOICE AND ACTION Motion Picture CENT/COR 14 min., sd., col.

Illustrates that non verbal elements such as voice tone an facial expression are an integral part of speech communic

COMMUNICATIONS ROADBLOCKS Motion Picture BFA 197715 min., sd., col.

biases, and distinguishing fefining terms, understandin

COMMUNICATIONS SERIES Motion Picture BARR/GORD WATT $198011-21$ min. ea., sd., col. cation process and its rela tionship to success. The titles are: "Communicating Effec-
tively" ,"What do we Look Like to Others", "Person to Person", "Communications or Confrontations".

COMMUNICATION SKILLS: TELL-SELL-RESOLVE VideOrecording GM/Marlin $197586 \mathrm{~min} .$, sd., col.
How and when to communicate appropriately in letters memos, meeting, etc.

COMMUNICATION SKILLS FOR MANAGERS Videorecording TIMLIF/MARLIN 1980

These six programs discuss, depict, and demonstrate listening, speaking, meetings and presentations.

COMMUNICATION PRIMER Motion Picture PYR/ITF 1954 22 min., sd., col.
This classic by Charles Eames reveals different concepts of communication, and shows the effect communication has

NADIAN JOURNAL OF EDUCATIONAL COMMUNICATION
COMMUNICATIONS THAT WORK Motion Picture EFM/IT $198435 \mathrm{~min}$., sd., col.
A new release which looks at elements common to writing speaking, and listening.

DECISIONS, DECISIONS Motion Picture VA/ITF 197928

Set in a business setting, this program explores attitudes an assumptions which contribute to communication break-

LISTENING FOR RESULTS Motion Picture RTBL/TTF 198

Common listening errors, and how they could be avoided, are the subject here.

UISTENING, SPEAKING, AND NON-VERBAL LANGUAG Describes and demonstrates the abuses and misuses, as well as the correct ways.

NON-VERBAL COMMUNICATION Motion Picture SAL MARLIN $197812 \mathrm{~min} .$, sd., col.
The topic here is how to be aware of non-verbal languag both oneself and others.

THE ONE-SIDED TRIANGLE: COMMUNICATION WITH IN THE GROUP Motion Picture BNA/TTF 197- $23 \mathrm{~min}$ sd., col.
The topic of this program is communication behavior at staf The topic of
meetings.

OH, WHAT A LOVELY REPORT Motion Picture RANK/IT 1926 min., sd., col.

investigation the ptrates the process of writing a report - the

OPEN THE DOOR Motion Picture CCCD/ITF 198- 28 min. sd., col.

PASS IT ON Motion Picture CCCD/TTF $198115 \mathrm{~min}$ sd col. Clarify and verify! This film demonstrates techniques for easy communication.

POWER OF LSTENING Motion Picture MGHT $197926 \mathrm{~min}$ sd., col.
With Dr. Stainbrook and Dr. Alessandra, the process of effe tive communication is explored, with listening being examined as an "active" function involving both listener and
speaker.

STRICTLY SPEAKING Motion Picture CCCD/ITF 197927 min., sd., col.
Based on Edwin Newman's books, this film deals with verbal behavior. 

speed setting of one second. The scan rate factors with display type and quality forewill always give better results than a color receiver, since if modulation and demodulation reduces resolution of the screen im-
age. It goes without saying that one should always select the most expensive and wel Monochrome monitors are also suitable for in exactly the same manner as a color display. lity, and processing. Good results have been achieved with Kodak Ektachrome
and Kodachrome daylight type film in the
ASA 200 range. Some experimentation is each wrame. Thus exposure time must b a risk of obtaining a partial frame. The image improves when the shutter remains open long enough to allow several separate times of a half second and one second seem Exposure and color are affected by the settings on the video display. If the display has detents (click-stops) on the col-
or shading, tint, contrast, and brightnes controls this provides a good starting point.
If such is not the case select an average set-
ting that looks good on the screen as the during future sessions.

\section{MEDIA PERIODICALS}

MEDIA \& METHODS, 21:3, November 1984 McKenzie, Jamieson A. "The future isn't what it used to be Videotex in on the way"
Hunter, C. Bruce and Allen L. Wold. "Basic guide to the com-
plete educational computer"

MEDIA IN EDUCATION AND DEVELOPMENT, 17:3, September 1984

McCormick, Bob. "Prospects and problems for China's TVUs"
Hosie, Peter and Tony Dean. "TV for isolated students in Western Australia"

With technologydistance training for industry"
Rodwell, Susie. "A world communications crisis?"

Hart, Andrew. "Not just a bit of an extra"
Higgins, John. "The computer and text"

PROGRAMMED LEARNING \& EDUCATIONAL TECHNOLOGY, 21:2, May 1984

Milne, J. A. and J.S.A. Anderson. "The microelectronics education programme-dissemination and diffusion of microelectronics technology in education"
Lloyd, G. "A model for the development by industry and commorce of multi-media resource packs for use in education
mestion PROGRAMMED LEARNING \& EDUCATIONAL

Oxley, Alan. "Computer-assisted learning (CAL) of structural Wyer, Jo-Anne. "New bird on the branch: artificial intelligence and computer-assisted instruction" Thompson, Vincent. "Information
and training: the CET view"
Oliver, Elizabeth. "The development of a computer database

for education" " "
Emms, Stephen J. "The M \& C's skillcentre CBT project" Vinegrad, M.D. "Learning by example: a CBT approach" Morrison, R.K. "Computer-based learning-the way ahead"
Telem, Moshe "Computer crimes in Telem, Moshe. "Computer crimes in schools"
in educational compute Morgan. "Aims and interest groups

MEDIOGRAPHY

Continued from page 13

WHAT DO YOU MEAN, WHAT DO I MEAN (CASE STUDIES IN COMMUNICATIONS) Motion Picture SAL/MARLIN $197618 \mathrm{~min}$., sd., col.
The focus here is the way we see ourselves and the way
we see others.

WITHOUT WORDS: AN INTRODUCTION TO NONATION Motion Picture PH/Marlin The effects and interation of non-verbal barriers on com-
munication are presented here. YU'RE NOT COMMUNICATING Motion Picture CF 1980 20 min., sd., col. way process and an understanding of the process improves
way communication. thed by starting with a shutter speed seting of one second and an aperture setting then, keeping shutter speed constant, shoot exposures at 44.5, f5.6, and f11. Then, with the same graphic, repeat the exposures second. Repeat this process with a different display. Make sure a test of light colored vs dark colored background is carried ou. film, exposure, and display settings it will and analyzed, to determine a standardized procedure which will ensure succes

own color computer gempt to make your they have the potential to revolutionize the manner in which you communicate educa plications" theme, the Congress will echnology equipment exhibit of high relating to education and culture from
around the world. dards introduc echnologies as a result of the new improve the quality of education pro
vided in respective jurisdictions Seven themes will take advantage of the breadth of experience brought to the Congress by the international participants
and speakers. These seven themes are: Teaching \& Learning

Theories of learning, new designs for
curriculum, teaching about and teaching curriculum, teaching about and teaching
with computers will be discussed as this heme focuses on the interaction betwee
the new technology and the classroom. Management \& Technology

The challenge inherent in managing educational community. Administrative applications - financial reporting,
scheduling communications, data banks, scheduling, communications, data banks,
office functions - will undoubtedly b. office functions - will undoubt
explored by congress participants.

Employment \& Training Technology is creating new opportunities for employment and career
preparation. An indepth look at these opportunities in the context of the changing workplace will be offered.

The Future Society

Congress participants are promised
crystal ball into the future, looking at how technology will affect our work, our play, culture, the environment and

Innovations \& Applications

Hardware and software take center
stage in a world-class exhibit and a variestage in a world-class exhibit and a varie-
ty of learning sessions designed to and unique applications to education.

Special Needs \& Interests

We will look at unique applications to including the education of the physicaly and mentally handicapped and the use of
technology as a means of bringing people
together.

Policy \& Planning

The effects of technology on human
values and goals; questions of privacy. values and goals; questions of privacy,
control and ethics in an information society...these are all part of a multi-faceted dialogue aimed at "rounding out" issues of education and technology.
By dividing the World Congress By dividing the World Congress into
themes, the face-to-face nature of a
smaller conference will be combined with the advantages of diversity tha characterize a larger gathering.
As part of the "Innovations and Ap plete program information available in plete program
September 1985

Questions concerning the World Congress on Education and Technology may Britis Columbia School Trustees
Association, 1155 West 8th Avenue, Association, 1155 West 8th Avenue,
British Columbia, Canada V6H 1C5 Telephone: (604) 734-2721.

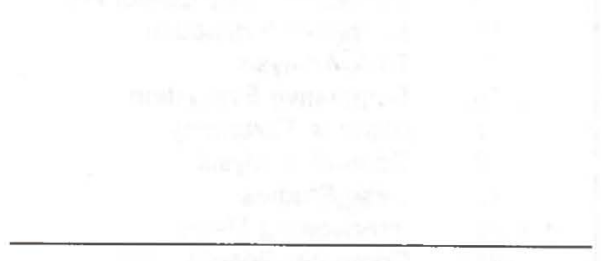

Film Showcase April 15-19, 1985

Objectives

Since the first FILM SHOWCASE In
1970, this event has been Canada's major marketplace for $16 \mathrm{~mm}$ non-theatrical films. It provides a unique opportunity
for $16 \mathrm{~mm}$ film producers/distributors to exhibit their newest films and video pro-
duct for library personnel, educators, film
society representatives society representatives, government of-
ficials and business people, all of whom have financial leverage in recommending film and video product. Film Showcase is not a forum for film workshops or screen

Location
FILM SHOWCASE will be held at the
YMCA Conference Centre Geneva Park YMCA Conference Centre, Geneva Park,
on Lake Couchiching, near Orillia, Ontario.

Program Format

Each day, twenty nine distribution companies will be operating 29 screening
areas simultaneously. This year all twenty-nine distributors will be attending
for the full week (Monday-Friday) Further Information

you have any special reeuirements

Jean Harding, Co-ordinato

22 Bardwell Crescent Scarborough, Ontario M1R 1C9

(416) 979-5097 or (416) 757-9517

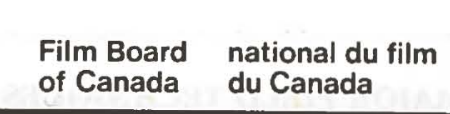

250

Films, Videocassettes and Early, discounted registration is Multi-Media Productions
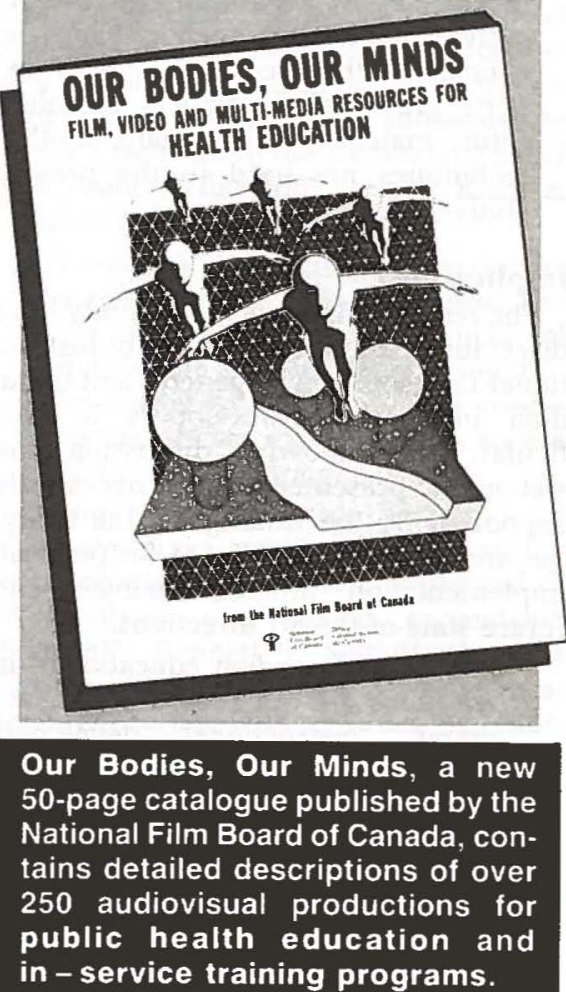

40 subject headings, including:

- Addictions - Mental Health

$\begin{array}{ll}- \text { Parenting } & \text { - First Aid and Satety } \\ \text { D.E.S. } & \text { - Violence Against Wome }\end{array}$

$\begin{array}{ll}- \text { Child Abuse } & \text { F Films tor Kids } \\ - \text { Death and Dying } & \text { Occcupationat }\end{array}$

- The Disabled

All NFB films may be borrowed free

in either $16 \mathrm{~mm}$ or videocassette for-

mats. Some
video rental.

Our Bodies, Our Minds is an

indispensable resource for:

- Cornmunity Health Educator

- Nursing and Medical Schools

To receive your complimentary copy of Our

National Film Board of Canada office or

Health Education Catalogue

English Marketing,
National Film Board of Canada,

Montreal, Quebec 